\title{
HUBUNGAN TINGKAT PENGETAHUAN DAN SIKAP PERAWAT TENTANG INFEKSI NOSOKOMIAL (INOS) DENGAN PERILAKU PENCEGAHAN INOS DI RUANG BEDAH RSUD DR. MOEWARDI SURAKARTA
}

\author{
Dwi Sulistyowati \\ Kementerian Kesehatan Politeknik Kesehatan Surakarta Jurusan Keperawatan
}

\begin{abstract}
Knowledge, Attitudes, Behaviors, Inos, Nurse. Nosocomial infections (inos) is an infection acquired during patient care in hospitals, infection is not in pain at the time of hospital admission and the patient is not within an incubation period of infectious diseases. The study aims to determine the relationship between the level of knowledge and attitudes to the behavior of nurses regarding the prevention of inos in the operating room of RSUD Dr. Moewardi Surakarta. Design used in this study was descriptive correlational cross-sectional approach. Sampling was carried out with total non-probability sampling, sample size of 30 respondents. There is a relationship between the level of the nurse's knowledge about preventive behaviors inos with a probalility value of Spearman's Rank correlation test for $p=0,024$ is smaller than the probability $p=0,05$. There is no relationship between nurse attitudes about preventive behaviors inos with a probability value of Spearman's Rank correlation test for $p=0.759$ greater than the probability $p=0.05$. There is a relationship between the nurse's knowledge about preventive behavior with inos. There is no relationship between attitudes to the behavior of nurses regarding the prevention of inos.
\end{abstract}

Keywords: Knowledge, Attitudes, Behaviors, Inos, Nurse.

\begin{abstract}
Abstrak: Pengetahuan, Sikap, Perilaku, Inos, Perawat. Infeksi nosokomial (Inos) adalah infeksi yang diperoleh selama penderita mendapatkan perawatan di rumah sakit, infeksi tidak di derita pada waktu masuk ke rumah sakit dan penderita tidak berada dalam masa inkubasi suatu penyakit infeksi. Penelitian bertujuan untuk mengetahui hubungan antara tingkat pengetahuan dan sikap perawat tentang inos dengan perilaku pencegahan inos di ruang bedah RSUD Dr. Moewardi Surakarta. Desain yang digunakan dalam penelitian ini adalah deskriptif korelasional dengan pendekatan cross sectional. Pengambilan sampel dilakukan secara non probability dengan total sampling, jumlah sampel 30 responden. Ada hubungan antara tingkat pengetahuan perawat tentang inos dengan perilaku pencegahan inos dengan nilai probabilitas uji korelasi Rank Spearman sebesar $\mathrm{p}=0.024$ lebih kecil dari probabilitas $\mathrm{p}=0,05$. Tidak ada hubungan antara sikap perawat tentang inos dengan perilaku pencegahan inos dengan nilai probabilitas uji korelasi Rank Spearman sebesar $\mathrm{p}=0,759$ lebih besar dari probabilitas $\mathrm{p}=0,05$. Ada hubungan antara pengetahuan perawat tentang inos dengan perilaku pencegahan inos tetapi tidak ada hubungan antara sikap perawat tentang inos dengan perilaku pencegahan inos.
\end{abstract}

Kata Kunci: Pengetahuan, Sikap, Perilaku, Inos, Perawat. 


\section{PENDAHULUAN}

Pengendalian inos menjadi demikian penting karena semakin canggihnya peralatan - peralatan di rumah sakit, namun disisi yang lain semua upaya pemeriksaan cenderung dilakukan dengan prosedur invasif. Perawat profesional yang bekerja di rumah sakit semakin hari semakin diakui eksistensinya dalam setiap tatanan pelayanan kesehatan, sehingga dalam memberikan pelayanan secara interdependen tidak terlepas dari kepatuhan perilaku perawat dalam setiap tindakan prosedural yang bersifat invasif tersebut seperti halnya perawatan luka operasi (Supratman, 2008). Inos adalah infeksi yang diperoleh selama penderita mendapatkan perawatan di rumah sakit. Infeksi ini tidak di derita pada waktu masuk ke rumah sakit dan penderita tidak berada dalam masa inkubasi suatu penyakit infeksi (Entjang, 2003). Pengetahuan merupakan aspek penting yang sangat fital dari keperawatan. Hubungan antara praktik keperawatan telah berubah sejalan dengan waktu dan hal ini dapat dianggap sebagai kemajuan yang telah melewati tiga fase yang berbeda (Basford, 2006). Perilaku kesehatan pada dasarnya merupakan respon seseorang terhadap stimulus atau objek yang berkaitan dengan sakit dan penyakit, sistem pelayanan kesehatan, makanan dan minuman serta lingkungan (Notoatmodjo, 2007). Teknik dasar yang paling penting dalam pencegahan dan pengontrolan penularan infeksi adalah mencuci tangan. Mencuci tangan adalah menggosok dengan sabun secara bersama seluruh kulit permukaan tangan dengan kuat dan ringkas yang kemudian dibilas di bawah aliran air
(Larson 1995, dalam Potter \& Perry, 2005). Tujuannya adalah untuk membuang kotoran dan organisme yang menempel dari tangan dan untuk mengurangi jumlah mikroba total pada saat itu.

\section{METODE PENELITIAN}

Desain yang digunakan dalam penelitian ini adalah deskriptif korelasional dengan pendekatan cross sectional. Populasi dalam penelitian ini adalah perawat di ruang $\mathrm{HCU}$ Bedah dan Mawar 2, RSUD Dr. Moewardi Surakarta dengan jumlah populasi 30 orang. Pengambilan sampel dilakukan secara non probability dengan total sampling dengan pertimbangan tertentu (Arikunto, 2006). Pada penelitian ini sampel di ambil dari seluruh perawat pelaksana di ruang $\mathrm{HCU}$ Bedah dan Mawar 2 RSUD Dr. Moewardi. Instrument penelitian dalam variabel dependen yaitu perilaku pencegahan inos dengan menggunakan lembar check list, sedangkan dalam variabel independen yaitu pengetahuan dan sikap perawat tentang inos dengan menggunakan kuesioner Check list perilaku pencegahan inos berupa standar pencegahan inos di RSUD Dr. Moewardi Surakarta, disusun dengan menggunakan skala Gutman dengan 2 alternatif jawaban

\section{HASIL PENELITIAN}

a. Distribusi Frekuensi Pengetahuan Responden

\begin{tabular}{llll}
\hline No & $\begin{array}{l}\text { Kategori } \\
\text { pengetahuan }\end{array}$ & Jumlah & $\begin{array}{l}\text { Persentasi } \\
(\%)\end{array}$ \\
\hline 1 & Tinggi & 16 & 53,3 \\
2 & Sedang & 11 & 36,7 \\
3 & Rendah & 3 & 10 \\
\hline Jumlah & 30 & 100 \\
\hline \multicolumn{3}{c}{ Berdasarkan } & tabel diatas \\
diperoleh dari 30 & responden yang \\
diteliti sebagian besar memiliki
\end{tabular}


pengetahuan tinggi tentang inos yaitu sebanyak 16 responden $(53,3 \%)$.

b. Distribusi frekuensi sikap responden

\begin{tabular}{|c|c|c|c|}
\hline No & $\begin{array}{l}\text { Kategori } \\
\text { sikap }\end{array}$ & Jumlah & $\begin{array}{l}\text { Persentasi } \\
(\%)\end{array}$ \\
\hline 1 & Baik & 10 & 33,3 \\
\hline 2 & Cukup & 15 & 50 \\
\hline 3 & Kurang & 5 & 16,7 \\
\hline \multicolumn{2}{|c|}{ Jumlah } & 30 & 100 \\
\hline
\end{tabular}

diperoleh dari 30 responden yang diteliti sebagian besar memiliki sikap cukup tentang inos yaitu sebanyak 15 responden $(50 \%)$.

c. Distribusi Frekuensi Perilaku Responden

\begin{tabular}{|c|c|c|c|}
\hline No & $\begin{array}{l}\text { Kategori } \\
\text { perilaku }\end{array}$ & Jumlah & $\begin{array}{l}\text { Persentasi } \\
(\%)\end{array}$ \\
\hline 1 & Baik & 18 & 60 \\
\hline 2 & Cukup & 8 & 26,7 \\
\hline 3 & Kurang & 4 & 13,3 \\
\hline \multicolumn{2}{|c|}{ Jumlah } & 30 & 100 \\
\hline
\end{tabular}

diperoleh dari 30 responden yang diteliti sebagian besar memiliki perilaku baik tentang inos yaitu sebanyak 18 responden (60\%).

Hasil Uji Korelasi Rank Spearman

\begin{tabular}{|c|c|c|c|}
\hline Variable & $\begin{array}{l}\text { Nilai } \\
\text { korelasi (r) }\end{array}$ & $\begin{array}{l}\text { Sign } \\
(2- \\
\text { tailed }) \\
\end{array}$ & Keterangan \\
\hline $\begin{array}{l}\text { Pengetahuan } \\
\text { *Perilaku }\end{array}$ & 0,426 & 0,029 & ada hubungan \\
\hline $\begin{array}{l}\text { Sikap } \\
\text { *Perilaku }\end{array}$ & 0,059 & 0,759 & $\begin{array}{l}\text { Tidak } \\
\text { ada } \\
\text { hubungan }\end{array}$ \\
\hline
\end{tabular}

Berdasarkan tabel 4.6 di atas diperoleh hasil uji statistik nilai probabilitas uji korelasi Rank Spearman sebesar $\mathrm{p}=0,029$ lebih kecil dari probabilitas $\mathrm{p}=0,05$, sehingga $\mathrm{Ho}$ ditolak dan $\mathrm{Ha}$ diterima atau ada hubungan antara pengetahuan perawat tentang inos dengan perilaku pencegahan inos. Nilai rho hitung pengetahuan dan perilaku 0,426 berada dalam rentang 0,40 sampai 0,599 yang berarti memiliki arah hubungan sedang. Sedangkan nilai probabilitas uji korelasi Rank Spearman sikap dan perilaku 0,759 lebih besar dari probabilitas $\mathrm{p}=0,05$ sehingga $\mathrm{Ho}$ diterima yang berarti tidak ada hubungan antara sikap perawat tentang inos dengan perilaku pencegahan inos. Nilai rho hitung sikap dan perilaku 0,059 berada dalam rentang 0,00 sampai 0,199 yang berarti memiliki arah hubungan sangat rendah.

\section{PEMBAHASAN}

Perilaku pencegahan inos Dari 30 responden yang diteliti diperoleh gambaran perilaku perawat dalam pencegahan inos di ruang bedah RSUD Dr. Moewardi sebagian besar dalam kategori baik sebanyak 18 responden (60\%). Hal ini didukung dengan hasil observasi yang dilakukan peneliti pada perawat di ruang bedah RSUD Dr. Moewardi bahwa kegiatan cuci tangan sebelum melakukan tindakan $30 \%$, cuci tangan setelah melaukan tindakan $100 \%$, menggunakan sarung tangan dalam melakukan tindakan 90\%, menggunakan masker saat melakukan tindakan $70 \%$, menggunakan gown saat melakukan tindakan $62,1 \%$.

Hal tersebut dipengaruhi beberapa faktor salah satunya tingkat pengetahuan perawat tentang inos dalam kategori tinggi sebanyak 16 responden (53,3\%). Menurut Notoatmodjo (2007) perilaku dipengaruhi beberapa faktor yaitu pengetahuan, kecerdasan, persepsi, emosi, motivasi dan sebagainya yang berfungsi untuk mengolah rangsangan dari luar. Selain itu, menurut Azwar (2003) Pengetahuan atau kognitif merupakan domain yang sangat penting untuk terbentuknya tindakan seseorang. Hal ini diperkuat dengan pendapat Notoatmajdo (2003) yang menyatakan bahwa penerimaan perilaku atau adopsi 
perilaku didasari oleh pengetahuan, kesadaran, dan sikap yang positif maka perilaku tersebut akan menjadi kebiasaan atau bersifat langgeng (long lasting). Sebaliknya apabila perilaku itu tidak didasari oleh pengetahuan dan kesadaran maka tidak akan berlangsung lama.

Dari hasil penelitian menunjukkan nilai probabilitas uji korelasi Rank Spearman sebesar $\mathrm{p}=$ 0.029 lebih kecil dari probabilitas $\mathrm{p}=$ 0.05 , sehingga Ho ditolak dan $\mathrm{Ha}$ diterima atau sehingga dapat disimpulkan ada hubungan antara pengetahuan perawat tentang inos dengan perilaku pencegahan inos. Hasil penelitian ini sejalan dengan hasil penelitian yang dilakukan oleh Fitria (2010) yang menyatakan bahwa ada hubungan antara pengetahuan keluarga tentang kegawatdaruratan trauma kepala dengan perilaku untuk mendapatkan pelayanan kesehatan. Dari hasil penelitian Rogers yang dikutip kembali oleh Notoatmodjo (2007) menyatakan bahwa pengetahuan atau kognitif merupakan domain yang sangat penting untuk terbentuknya tindakan seseorang.

Dari hasil penelitian yang didapatkan, tingkat pengetahuan perawat tentang inos dengan perilaku pencegahan inos bervariasi. Dari hasil jawaban kuesioner tingkat pengetahuan perawat tentang inos dikategorikan tinggi $(53,3 \%)$, dan dari hasil observasi perilaku perawat dalam pencegahan inos dalam kategori baik $(60 \%)$.

Dari hasil penelitian menunjukkan nilai probabilitas uji korelasi Rank Spearman sebesar $\mathrm{p}=$ 0.759 lebih besar dari probabilitas $\mathrm{p}=$ 0.05 , sehingga dapat disimpulkan tidak ada hubungan antara sikap perawat tentang inos dengan perilaku pencegahan inos. Hasil penelitian ini sejalan dengan hasil penelitian yang dilakukan Asfriyati (2010) yang menyatakan bahwa tidak ada hubungan antara sikap tentang infeksi menular seksual (IMS) dan perilaku pemakaian kondom dalam upaya pencegahan IMS. Hal ini juga sejalan dengan hasil penelitian yang dilakukan Abdullah \& Sudjarwo (1993, dalam Azwar 2003) yang mengungkapkan bahwa sikap yang positif terhadap sesuatu tidak menimbulkan adanya perilaku yang positif, yang berarti adanya hubungan yang lemah antara sikap dan perilaku. Menurut Azwar (2003) hubungan antara sikap dan perilaku memang belum konklusif, banyak penelitian yang menyimpulkan adanya hubungan yang sangat lemah bahkan negatif, sedangkan sebagian penelitian lain menemukan hubungan yang meyakinkan. Walaupun sikap seseorang baik belum tentu memiliki perilaku yang baik pula karena perilaku dipengaruhi beberapa faktor yaitu pengetahuan, kecerdasan, persepsi, emosi, motivasi dan sebagainya yang berfungsi untuk mengolah rangsangan dari luar (Notoatmodjo, 2007). Sikap terhadap suatu perilaku dipengaruhi oleh keyakinan bahwa perilaku tersebut akan membawa kepada hasil yang diinginkan atau tidak diinginkan (Azwar 2003). Teori tindakan beralasan yang dikemukakan oleh Martin Fishbein yang dikutip kembali oleh Azwar (2003) mengatakan bahwa sikap mempengaruhi perilaku lewat suatu proses pengambilan keputusan yang teliti dan beralasan, dan dampaknya terbatas hanya pada tiga hal. Pertama, perilaku tidak banyak ditentukan oleh sikap umum tetapi oleh sikap yang spesifik terhadap sesuatu. 
Kedua, perilaku dipengaruhi tidak hanya oleh sikap tetapi keyakinan. Ketiga, sikap terhadap suatu perilaku dan keyakinan membentuk niat untuk berperilaku tertentu.

\section{KESIMPULAN DAN SARAN}

Sebagian besar pengetahuan perawat tentang inos dikategorikan tinggi, sikap perawat tentang inos dikategorikan cukup, perilaku perawat dalam mencegah inos dikategorikan baik dan ada hubungan antara pengetahuan perawat tentang inos dengan perilaku pencegahan inos dan tidak ada hubungan antara sikap perawat tentang inos dengan perilaku pencegahan inos .Perilaku pencegahan inos dan standar/ pedoman pencegahan inos yang dibuat Panitia Pengendalian Infeksi Nosokomial (PANDALIN) di RSUD Dr. Moewardi Surakarta.selalu terevaluasi

\section{DAFTAR RUJUKAN}

Azwar. 2000. Sikap Manusia. Yogyakarta : Putaka Pelajar Offset.

Basford, Lynn. Slevin, Oliver. 2006. Teori dan Praktek Keperawatan. Jakarta: Penerbit Buku Kedokteran: EGC.
Entjang, I. 2003. Mikrobiologi dan parasitologi. Jakarta : Widya Medika.

Morison, Moya J. 2004. Manajemen Luka. Jakarta : EGC.

Pariani, Siti. 2001. Metodologi Penelitian. Jakarta: Penerbit Andi Offset.

Potter \& Perry. 2005. Fundamental Keperawatan vol I Buku Ajar Konsep Proses dan Praktik Edisi 4. Jakarta: Penerbit Buku Kedokteran EGC dan Mosby.

Schaffer, Susan D. dkk. 2000. Pencegahan Infeksi dan Praktik yang Aman. Jakarta: Penerbit Buku Kedokteran EGC.

Supratman \& Setiyawati, Wiwik. 2008. Berita Ilmu Keperawatan Journal News in Working. Surakarta: Program Study Ilmu Keperawatan Fakultas Ilmu Kesehatan UMS.

Sutopo, 2002. Metodologi Penelitian Kualitatif. Surakarta : Sebelas Maret University Press.

Spiritia. 2005. Angka kejadian Infeksi nosokomial di Rumah Sakit. www.indomedia.com.

Diperoleh pada tanggal 20 mei 2009. 